\title{
"I Have Mandated It to Fly to You on the Wings of My Ardent Desire"
}

\author{
Letter to the Prophet Written by Lisān al-Dīn ibn al-Khațīb (d. 776/1375) \\ on Behalf of the Nașrid Ruler of Granada
}

Nelly Amri

The literary genre of letters addressed to the Prophet in his tomb (al-rawda alnabawiyya), hailing him and asking for his intercession in worldly and eschatological matters (wa al-tashaffu' bihi ilā Allāh fì l-maqāsid al-dunyawiyya wa l-ukhrawiyya) (al-Qalqashandī), was particularly popular in al-Andalus; ${ }^{1}$ the author of the Subh al-Ashā describes this genre as a speciality of the people of the Maghrib because, he writes, of the remoteness of their homeland (bu'di bilādihim wa nuzūh aqtārihim). ${ }^{2}$ The immediate motivation for the writing of such letters seems to be the inability of their authors, and of the people commissioning them, to visit the holy places of the Hijāz and perform the ziyāra at the Prophet's tomb; these letters also provided an opportunity for their authors to express in a direct style their feelings of yearning at being far from Medina and the holy sanctuary of Mecca, and their love for and attachment to the Prophet, whose noble virtues and eminent qualities they praise, along with the marks of his election by God; they also express their personal worries, grievances and complaints. They seek a guarantee of baraka, but beyond this they wish for some consolation, comfort, and support in the here and now, and intercession in the next world. These letters make up a specific genre, ${ }^{3}$ one that has something in common with the literature of madāih (panegyrics),

1 I would like to thank Denis Gril for his enlightening insights and suggestions for the translation of certain passages.

2 Qalqashandī, Șubh al-A'shā, 6:469. Although Andalusians were particularly fluent in this genre, it was not unknown in Ifrīqiyā, where scholars did not hesitate to write such letters addressed to the Prophet in his tomb when they had undergone some trouble, or as a sign of gratitude or grace, or, finally, to express their yearning and love for the Prophet. 'Abd al-Wāhid Muhammad b. al-Tawwāh (d. after 718/1318), a Sufi scholar from Tunis, was comforted, when he was suffering a crisis (ubtulitu bi-baliyyatin) in 704/1304, by a dream-vision of the Prophet, and wrote a letter to him in his tomb, entitled Nuzhat al-ahdāq wa rawdat al-mushtāq, which is published in extenso in Ibn al-Ṭawwāh, Sabk al-maqāl, 97-101.

3 See below. For more on this type of letter, classed among "religious letters" (al-rasā̉il al-dīniyya), see (notably) Falāḥ al-Qaysī, Adab al-Rasā̉il, 194-98. 
khașāiș, and shamāil (treatises of prophetology). The eighth/fourteenth century was marked everywhere in the Maghrib by an upsurge of forms of piety and devotion to the Prophet: starting in the seventh/thirteenth century, across the east and the west of the Muslim world, including the Nașrid court, the celebration of the Prophet's birth (mawlid) was the most outstanding example of this. In addition, his heirs (or presumed heirs) came to be subjects of particular veneration and recipients of economic and social privileges; in the construction of authority and legitimacy the status of the sharaf (ancestry dating back to the Prophet) becomes an important reference point. From the sixth/ twelfth century, a whole literature on the merits of the prayer on the Prophet ( fadll al-șalāt 'alā al-nabì) develops, especially in al-Andalus: just for the sixth/ twelfth and seventh/thirteenth centuries no fewer than fourteen treatises of this type have been accounted for; nine of these were specifically Andalusian. ${ }^{4}$ From the eighth/fourteenth century there was a measurable increase in the production of such texts across the whole Muslim world, both east and west. ${ }^{5}$

According to al-Qalqashandī, the letter written in the name of the Nașrid sovereign of Granada ${ }^{6}$ Abū al-Ḥajjāj Yūsuf b. Ismāeil b. Nașr (r. 733-55/1333-54) by Ibn al-Khațib, the text of which al-Qalqashandī published in extenso in his Șubh $a l-A$ s $s \bar{a},{ }^{8}$ was "the best he has ever seen" (min ahsani mà ra'aytu fi al-ma'nā) in the genre of letters addressed by people of the Maghrib to the Prophet after his death. ${ }^{9}$ Ibn al-Khațīb wrote another letter to the Prophet, this time on behalf of the son of Yūsuf I, al-Ghanī bi-llāh Muhammad b. Abī al-Ḥajjāj (r. 7556o/1354-9 and 763-93/1362-91); the two letters, published by Ibn al-Khațîb himself in the Ihăța ${ }^{10}$ and in Rayhănat al-kuttāb wa-nujat al-muntāb ${ }^{11}$ were reissued by al-Maqqarī in his Naf̣ al-țîb $b^{12}$ (and have since been cited mostly from this source); the letters share a similar structure and touch more or less

Hamidoune, "La pratique de la 'prière sur le Prophète", 49-51.

The Nașrid kingdom in the far south of Spain covered the area that is now the eastern part of Cadiz province and the provinces of Malaga, Granada, and Almeria. Al-'Umarī, the author of the Masālik al-Abșār and a contemporary of the Nașrid ruler Yūsuf I, travelled throughout al-Andalus in 738/1337; at the time it took three days to cross the width of the Nașrid kingdom on foot, and ten days to cross its length; see Arié, "Al-Andalus", 165. For more on the history of the Nașrids, see Latham, "Nașrides", 1022-30, A. For more on him, see Ibn al-Khațīb, $A^{\prime} m \bar{a} l$ al-A'ām, Second Section: $264-5$, and, from the same author, al-Lamha al-badriyya, 127-138.

8 Qalqashandī, Șubh al-A'shā, 6:469-76.

9 Qalqashandī, Șubh al-A'shā, 6:469.

10 Ibn al-Khațīb, Ihāța, 5: 859-78 for the first letter, and 879-928 for the second.

11 Ibn al- Khațîb, Raỵ̂anat al-kuttāb, 1:55-62 for the first letter, and 1:62-8o for the second.

12 Maqqarī, Nafth al-țīb, 6; respectively 354-36o and 36o-379. 
on the same themes, but the second of them focuses on an account of the battles and victories of Muhammad al-Ghanī bi-llāh ${ }^{13}$ that dominates the entire text. This second letter, written at the beginning of $771 / 1369,{ }^{14}$ was carried by a messenger to the holy places of the Hijāz the same year, during the month of Rabi` al-awwal (the month of the Prophet's birth). The messenger who carried it ${ }^{15}$ also brought two other missives from the Nașrid, one addressed to Șāhib Makka, 'Ajlān ibn Asad al-Dīn Abū al-Faḍl Rumaytha b. Muḥammad b. Abī Sa'd Al-Hasan ${ }^{16}$ and the other to the Prince of Medina, ${ }^{17}$ informing them of the letter to the Prophet in which, he says, details of Muslim victories (nu'arrifuhu bi-hādhihi al-barakāt) are "brought to his attention". With these letters were sent bells that had been taken in the battles (nawāqis al-faranj), so that they could be displayed to pilgrims as a reminder of these glorious victories, and so that "prayers and invocations might be addressed to God in those noble places, that victory over their enemies should be granted to the armies of Islam (tastad'ī al-imdād bi-l-du'ä̉ wa taqtadì bi-tilka al-ma'āhid al-sharīfa al-nașr 'alā al-a $\left.{ }^{\mathrm{C}} \bar{a}^{3}\right){ }^{\prime 18}$ Unfortunately, we do not have any comparable information about the first letter, written in the name of Abū al-Hajjāj. This first letter is not dated, but in it the memory of the Nașrid battles against the "Catholic kings" is still fresh. The Nașrids were unable to face the intrigues of their Christian neighbours alone, and in the absence of effective support from the Egyptian

13 Maqqarī, Nafth al-țīb, 6: 367-378 (almost two thirds of the letter).

14 Ibn al-Khațîb, Ihậța, 5:879. Not 761/1359 as stated in Ibn al-Khațīb, Rayhānat al-kuttāb, 1:63; for obvious reasons of chronology, the victories related in the letter date from $768 / 1366-7$ and $769 / 1367-8$.

15 Might this be the faqīh Abū al-Hasan al-Bannā, the same messenger who had during the previous year (770/1368), in the month of Rabī ${ }^{`}$ II, carried a letter and gifts to the Hafsid Sultan of Tunis, Abū Isḥāq Ibrāhīm b. Abī Bakr (r. 751-70/1350-69) (for more on him, see Zarkashī, Tārīkh al-dawlatayn, 187-212), informing him of the victories of al-Ghanī bi-llāh (Ibn al-Khațīb, Rayhānat al-kuttāb, 1:179)?

16 'Ajlān (d. 777/1375) succeeded his father Rumaytha in 746/1345 in an atmosphere of bitter competition between himself and his brothers, especially Thaqaba. At the end of his life he passed power on to his son, Aḥmad; see the entry on him in al-Fāsī, al-Iqd al-thamīn, 6:58-73. In Ibn al-Khațīb, Rayḥānat al-kuttāb, 1:206, his genealogy, claiming descent from Abī Sa'ìd al-Husaynī, is incorrect; the sharîfs of Mecca are descended from the Hasanite branch (which goes back to Qatāda b. Idrīs al-Ḥasanī, see al-Fāsī, al-Iqd al-thamīn, 6:58), whereas those of Medina are descended from the Husaynite branch, see below.

17 Ibn al-Khațīb, Rayhānat al-kuttāb, 1:213-5. The prince in question appears to be 'Ațiyya b. Manșūr b. Jammāz b. Shīḥa b. Hāshim b. Qāsim b. Muhannā b. Husayn, who, according to Sakhāwī's account, became Prince of Medina in 759/1358; the following year (76o/1359) his investiture by the Mamluks took place. In $773 / 1371$ he was removed from power by a nephew, and returned to lead the Holy City in $782 / 1380$, dying the following year. See Sakhāwī, al-Tuhfa al-lațīfa, 1:56-7, and Maqrīzì, Durr al-'uqūd al-farìda, 1:569. 
Mamluks, who proved to be "purely passive", 19 their dependence on help from Morocco's Marinid Sultanates, solicited directly in Abū al-Hajjāj's letters, ${ }^{20}$ increased; this assistance was often decisive. ${ }^{21}$ The $j i h \bar{a} d$ on the frontiers played a central role in the rivalry for legitimacy and recognition of Caliphal dignity between the monarchs of the two countries. ${ }^{22} \mathrm{Ibn}$ al-Khațib's letter is part of a genre, and many of its themes, and even its structure, arise from that genre but it also contains community motifs that are closely related to the situation in which the Nașrid Sultanate of Granada found itself, motifs of "political" significance, with, in the background, the Caliphal pretensions of the monarch, and also some more personal motifs relating to the economy of salvation. These give Ibn al-Khațib's letter a certain specificity. Written as a result of particular circumstances, and seeking to project a certain image of the sovereign and his relationship with the Prophet, which is the basis of his authority and his political and religious legitimacy, Ibn al-Khațib's letter is nevertheless part of the devotion to the Prophet that developed strongly from the twelfth century, especially devotion to his figure as a source of succour here and in the next life. It is this figure on whom the faithful ('ulamā', scholars, political figures etc.) call in times of adversity, and to whom they address grievances and complaints. How do the contingencies and demands of the times interact with this devotion, and with its unvarying elements: expressions of profound love and veneration for the Prophet and his merciful figure that here take the form of letters addressed to him? Such letters demonstrate the permanence of the

19 Rachel Arié writes: "No effective aid was ever envisioned in order to save Islam in Spain, which was dying"; for more on the relationship with Egypt's Mamluks, see Arié, "Les relations diplomatiques", 93-7. On the Nașrid search for support from the Mamluks in order to reduce the kingdom of Granada's dependence on its southern neighbour in the struggle against the Christians, see Dejugnat, "La mer, miroir de la légitimité", 85-101.

20 As happened twice in 750/1349, see Ibn al-Khațīb, Rayhānat al-kuttāb, 1:359-65 and 365-72.

21 See Latham, "Nașrides", 1025. According to some authors, the support offered by the Marīnid Sultanate to the Nașrids for the survival of the kingdom of Granada should not be over-emphasised; more important might have been the role played by "the social and political instability that affected Castile during the last decades of the thirteenth century and all of the fourteenth", Torremocha Silva, "Les Nașrides de Grenade", 78. The rivalry between the kingdoms of Castile, Portugal and Aragon is also cited.

22 See Dejugnat, "La mer, miroir de la légitimité", 85-101. Ibn al-Khațîb, who calls both Abū al-Ḥajjāj Yūsuf and the Marīnid by the title Amìr al-Musliminn (prince of Muslims), adds, on the subject of Abū Inān, who succeeded his father Abū al-Ḥasan, that he had adopted the Caliphal title al-Mutawakkil 'alā Allāh; Ibn al-Khațīb, al-Lamha al-badriyya, 131. For his part, the Nașrid Yūsuf I had adopted the Caliphal honorific with billāh, Mu'ayyad billāh, Dejugnat, op. cit. and Latham, "Nașrides", 1022. His successors, Muḥammad v, Yūsuf II (r. 793-4/1391-2) and Yūsuf III (r. 810-20/1408-17) were respectively to adopt the names al-Ghanī bi-llāh, al-Mustaghnī bi-llāh and al-Nāṣir li-dīn Allāh, ibid. (See below). 
Prophetic presence, constantly actualised by the practice of the tawassul and the istighätha. We will examine these questions here.

We propose first to outline the contours and structure of a literary genre that was already at least three centuries old in our author's day, and examine some of the models from which he drew inspiration. Then we will evoke the man known as Dhü al-wizäratayn, (the one who unites the two functions of Vizier, that of the army and that of the pen) whose biography is very well-known, focusing on his relationship with the commissioner of the letter, the Nașrid Sultan, and on the context in which this occurred. In a third section we will analyse the letter itself, considering it in its entirety, as a literary production, examining particularly its representation of the Prophet and his figures, his role in this world and in the economy of salvation, as well as the marks of his active and living presence in the community. We will take a special interest in the Prophetic heritage claimed for the Nașrid, notably in the context of jihād. We will also study the personal, intimate and affective relationship between the sender and the Prophet, and the devotional aspect of the text, referring to the ritual of the ziyarra.

\section{$1 \quad$ A Genre and Its History}

This particular epistolary genre was not new in the eighth/fourteenth century. It had blossomed in the fifth/eleventh century, in the specific conditions that obtained in al-Andalus after the fall of the Umayyad Caliphate of Cordoba and the fragmentation of power during the era of the Taifa kingdoms (399-483/1008-109o), with their constant wars that were followed by Christian offensives against Islamic possessions in the Iberian Peninsula. The genre developed continuously through the subsequent centuries, alongside an upsurge of practices expressing devotion to the Prophet, spurred by the increasing difficulty of travelling to the Holy Places in Mecca and Medina: in the specific circumstances of the Muslim west, giving priority to jihād, numerous Maghribi jurists had reached decisions ( fatwā-s) that had effectively forbidden the performing of the haij (pilgrimage) for people from this region; ${ }^{23}$ undertaking the pilgrimage was ruled to bring no reward to those who persisted, in spite of everything, in accomplishing it; they were enjoined to put

23 As a reaction to these consultations, the Moroccan Sufi Abū Muhammad Șāliḥ (d. 631/ 1234), with the help of his sons, put in place a network of stages and relays to make it easier for Maghribi pilgrims to get to Medina; Dhahbī, Abū Muhammad Șāliḥ, 64-8o; Ferhat, "Le culte du Prophète", 9o-91. 
off their travels. ${ }^{24}$ In spite of the encouragement, under the Marinids, to begin making the pilgrimage again, ${ }^{25}$ it remained difficult to fulfil this canonical obligation: the routes were perilous by land and sea; by sea it was often necessary to embark on Christian ships. The principal deterrent, though, was the need to practise jihā.$^{26}$ In his letter to the Sharîf of Mecca, Ibn al-Khațīb emphasises: "jihād and pilgrimage are two brothers [...], of almost equal worth and bringing almost equal reward (wa-yakād an yatakāfáānfì al-muhāasaba)". ${ }^{27}$

In al-Andalus from the fifth/eleventh century, a risäla was any writing addressed by a secretary $(k \bar{a} t i b)$ to another person. This "writing" could even be a poem, ${ }^{28}$ leading some to assert that the genre is closer to poetic writing than to prose. ${ }^{29}$ Thus it is not surprising that letters to the Prophet, such as the one written by Ibn al-Khațib, often begin with a poem. By the eighth/fourteenth century the genre was already well-respected and al-Maqqarī, in his $A z h \bar{a} r$ al-riyā f fi akhbāa 'Yyā d, mentions numerous 'ulamā', poets, and scholars from the Maghrib and al-Andalus whose letters became famous. One of the earliest such letters was written by the faqīh and secretary (al-kātib) Muhammad b. 'Abd Allāh b. al-Jadd (d. 415/1024), who writes as a pilgrim who has just left the sanctuary in Mecca and the Prophet's tomb in Medina, and is expressing his love for the Prophet (wa qalbi bi-hubbi-ka ma'mūr wa-ma'hūl), allowing free reign to his regret at having left the holy tomb behind, and describing his deep longing for it now that he is far away (lahiqani min al-asaf li-bu'di mazāri-ka). The author invokes the Prophet directly ( $f a-l \bar{a}$ tansā lì yā rasūl Allāh), both as refuge and recourse, and by describing his haste to visit the tomb, that he might be granted the Prophet's shafāa $a$ on Judgement Day. Al-Jadd invokes God, asking Him to facilitate a return to the Holy Places, and a new visit to the Prophet's tomb, again so that he might be blessed with the Prophet's intercession on Judgement Day. ${ }^{30}$ Among the best-known authors of letters to the Prophet is Abū 'Abd Allāh Muhammad b. Mas'ūd b. Abī al-Khișāl (d. 540/1146), a faqīh, traditionist, historian, poet and Andalusian Vizier, known as "Dhü

24 Wansharīīi, Míyār, 1: 432. In fact, this was a debate on the legal obligation to undertake the hajj; the undertaking was subject to the individual's capacity to reach the Holy Places safely; Ibn Rushd had already considered this not to fulfil the canonical conditions (li-'adam al-istițấa) required to make this farḍ licit (wa-hiya al-qudra 'alā al-wușūl ma'a al-amn 'alä al-nafs wa-al-mäl).

25 "The opportunity to fulfil this sacred duty had not presented itself for a long time", writes Ibn Khaldūn, cited in Arié, "Les relations diplomatiques", 103.

26 For more on this debate, see Ḥaqqī, "Al-hajjf fil-Maghrib wa al-Andalus" 84-101.

27 Ibn al-Khațīb, Rayhānat al-kuttāb, 1:209.

28 Falāḥ al-Qaysī, Adab al-Rasā̉il, 79 .

29 Falāḥ al-Qaysī, Adab al-Rasāil, 8o.

30 Ibn Bassām, al-Dhakhīra, II, 1:286-8 and Falāḥ al-Qaysī, Adab al-Rasāill, 194-48. 
al-wizäratayn" ${ }^{31}$ Al-Maqqarì's Azhär al-riyād preserved the text of the letter al-Khișāl wrote (on his own behalf) to the Prophet, ${ }^{32}$ as well as the text of a letter he wrote for a certain 'Abd Allāh b. 'Abd al-Ḥaqq al-Ṣayrafì, of Cordoba, who suffered from paralysis - as soon as this letter arrived in Medina, al-Ṣayrafì was immediately healed. ${ }^{33}$ Qāḍi 'Iyāḍ (d. 544/1149) himself addressed a letter to the Prophet's tomb, which is also reproduced by al-Maqqarī in his $A z h \bar{a} r{ }^{34}$ Ibn al-Sīd al-Bațalyūsī (d. 521/1127) (sometimes transcribed as al-Bațalyawsī), a faqih , traditionist, philosopher, poet and grammarian, ${ }^{35}$ also sent a letter to the Prophet's tomb. Another Andalusian who excelled in the genre was Abū al-Ḥasan 'Alī b. al-Ghammād (d. 530/1135); so did Abū Zayd 'Abd al-Raḥmān al-Fazāzì (d. 627/1229-1230). A letter to the Prophet is also attributed to Abū 'Abd Allāh Muḥammad b. al-Jannān al-Andalusī al-Anșārī (d. in Bijāya between $646 / 1248$ and 648/1250); he was a traditionist, jurist, and writer of prose and poetry. He was born in Murcia and in 641/1243 sought refuge in Sabta after the seizure of his home city by Alphonse of Castile. Eventually he settled in the Ifrīqiyan port city of Bijāya, where he remained until his death. He was known to be shä ir al-madīh al-nabawi (a panegyrist of the Prophet). ${ }^{36}$ The existence of these scholars and writers, who wrote letters to the Prophet not just for themselves but also for others, confirms the idea of a veritable genre, in which ordinary people, as well as the élite and sovereigns, took part.

These letters share an easily recognisable structure whose elements can be found in the letter by Ibn al-Khațib. Authors begin with the basmala and the taşliya or "prayer on the Prophet"; this is followed by a list of the qualities, attributes, names and noble characters that God has given him, concentrating especially on his eschatological figure and the universal dimension of his mission, and on his miracles and other specific graces. Then the object of the letter is detailed, along with a presentation of its author and of his firm respect for the sunna and attachment to the Prophet's message, his love and yearning for the Prophet and his profound sorrow and regret that he has been unable to visit his tomb. Some authors, such as Qādī 'Iyāẹ, confess their sins of omission and commission, and their disobedience, at this stage. When the Prophet's

\footnotetext{
31 Ibn Abī al-Khișāl, Rasā̉il.

32 Maqarrī, Azhār al-riyāẹd, 4:20-29.

33 Maqarrī, Azhār al-riyāẹ, 4:29-31.

34 Maqarrī, Azhār al-rìyāẹ, 4:11-20.

35 For more on him, see Maqarrī, Azhār al-riyāẹ, 3:103 and subsequent.

36 For more on him, see Maqarrī, Naf̣̣ al-țīb, 7:415; see also Ghubrīnī, 'Unwān al-dirāya, 349, footnote 108; Ibn al-Jannān, Dīwān. For more on his madīh nabawī or al-nabawiyyāt, see Ibn al-Jannān, Dīwān, 25-30; in addition, its editor has written several works on Ibn al-Jannān and his madịh nabawī, the references for which feature in this text.
} 
tomb is mentioned, the memory of the Holy Places of the Hijāz and their sacred Prophetic history is invoked (the descent of the revelation, the Night of Power, etc.). There follows a series of invocations to God, in order to facilitate the ziyarra and obtain for the author the sweetness of proximity, with protection and forgiveness of sins, and guidance on the path of the Prophet. Then the writer addresses the Prophet directly, requesting his intercession on the Day of Judgement by virtue of his "praised estate" (al-maqāmal-mahmūd), because of which his succour is sought; the author then calls on his letter to stand in for him, so that by the Prophet's mediation God might convey upon him the benefits of having visited the tombs of the Prophet and his two companions (buried at his side), the first Caliphs Abū Bakr al-Ṣiddīq (r. 11-13/632-4) and 'Umar b. al-Khațāa (r. 13-23/634-644); he will also receive the benefits of having visited all the places that are closely linked with the holy history of Muhammad, the people of his house, his wives, his aṣhāb, (in some letters, such the one written by Ibn Abī l-Khișāl, these Companions are mentioned specifically). Finally, the letter ends with an invocation asking God to offer a profusion of salutations and blessings to the Prophet.

\section{The Man and the Letter in Their Time}

\subsection{Ibnal-Khațīb}

Regarding Ibn al-Khațī ${ }^{37}$ I repeat what E. Chaumont wrote about Ibn Khaldūn: "he is a personality who no longer requires any introduction". ${ }^{38}$ In fact, the two men were friends and have a great deal in common. Here I will discuss only the part of Ibn al-Khațib's life that concerns us, while he was in the service of the Nașrid Yūsuf I, in whose name he addressed this letter to the Prophet. Ibn al-Khațib entered the service of the seventh monarch of the Nașrid state of Granada, Sultan Abū al-Ḥajjāj Yūsuf b. Ismācīl, as a secretary after the death of his father at the battle of Rio Salado (Tarifa) in 741/1340. He and the Sultan were almost the same age (wa sinni yawma'idhin qaribun mi sinnihi); 39 they were close, and he was a favourite with the young monarch, but he was under the administrative and technical direction of the Vizier Abū al-Hasan 'Alī b. al-Jayyāb. When the latter died of plague in 749/1349, Ibn al-Khațîb was elevated to the function of kätib al-insh $\bar{a}$, chief of the royal chancellery, ${ }^{40}$ with

37 For more on him, see Bosch-Vilà, "Ibn al-Khațīb", 859-6o.

38 Chaumont, "l'Ego-histoire d'Ibn Khaldūn", 1041.

39 Ibn al-Khațīb, A'māl al-A'lām, 265.

40 Ibn al-Khațīb, Al-Lamha al-badriyya, 129. 
the title of Vizier. He retained these functions under the reign of al-Ghani billāh, Yūsuf's son, who acceded to the throne after his father's assassination in 755/1354; it was at this time that the elevation of his rank and category led him to take the title of Dhü al-wizäratayn. The letter whose contents we analyse and attempt to understand is not some trivial text: it comes from a man of whom it has been said that he offered "almost unique witness to history and culture at the end of the seventh/thirteenth century and through most of the eighth/fourteenth"; ${ }^{41}$ this was a culture in which the presence of the Prophet and the signs of veneration of his person occupied an important place: did not Ibn al-Khațīb himself compose numerous panegyrics to the Prophet and many mawlidiyyāt to be recited (especially at the court of Abū l-Hajjāj Yūsuf ${ }^{42}$ ) during celebrations of the Prophet's birth? Ibn al-Khațib was a man who belonged to the intellectual, literary and political élites, all deeply impregnated with Sufism. These different circles to which the author belonged interact in the contents of the letter, beyond the formal and stylised elements common to many missives of this type.

\subsection{The Context}

As we have mentioned, the letter composed by Ibn al-Khațīb for the Nașrid Abū 1-Hajjāj Yūsuf bears no date. It could have been written at any time between 749/1349, the year in which the writer replaced his master Ibn al-Jayyāb as Vizier and kātib al-insh $\bar{a}$, and 755/1354, the year in which Abū l-Hajjāj was assassinated; it may even have been composed during Ibn al-Jayyāb's lifetime, when our author had already assumed the function of kātib for the young monarch, since it was as bearer of this title that, in 748/1347, he accompanied the Nașrid sultan on a tour of the eastern limits of his kingdom. ${ }^{43}$ In any case, the context is redolent of the last battles of the Nașrid against his Christian neighbours, whose echoes are present in the letter to the Prophet. In the entry devoted to Yūsuf I in his $A^{\prime} m \bar{a} l a l-A^{\prime} l a ̄ m$, Ibn al-Khațîb informs us that Yūsuf I led the battle of Ṭarifa (Rio Salado) in 741/1340 alongside the Marīnìd Abū al-Ḥasan (whose son had just died in one of the skirmishes), facing the armies of Alphonse XI of Castile and his brother-in-law Alphonse IV of Portugal; the battle ended in defeat for the two Muslim armies. ${ }^{44}$ Subsequently, Abū al-Ḥasan retreated to his home in Morocco, while Yüsuf returned to Granada. On both sides the

\footnotetext{
41 Bosch-Vilà, "Ibn al-Khațîb", 86o.

42 See Kaptein, Muhammad's Birthday, 131-2. For more on these mawlidiyyāt, see Nūriyya, “Mawlidiyyāt Lisān al-Dīn", 115-136.

43 This tour was recounted by Ibn al-Khațîb, Khațrat al-țayf, 31-56; see also Dejugnat, "La mer, miroir de la légitimité" op. cit.

44 See also Ibn al-Khațīb, al-Lamḥa al-badriyya, 130-1.
} 
retreat had profound repercussions: the Muslims had not faced such a defeat since al-'Uqāb (Las navas de Tolosa, in 6o9/1212); ${ }^{45}$ the Christians, on the other hand, were reminded of that very victory, which marked the beginning of their ascendency over the Muslims and the gradual loss of Muslim territories in al-Andalus. The reign of Yūsuf I would be marked by additional defeats, as Ibn al-Khațib testifies: Qal'at Yaḥsub, also called Qal'at Banī Sa'īd, north-east of Granada (today's Alcala la Real), and al-Jazīra al-Khaḍrā' (Algesiras); ${ }^{46}$ this last defeat came after a lengthy siege in $742 / 1341$; in taking the city, Alphonse XI benefited from reinforcements from across Europe, including England. Because of its strategically important location at the southern-most tip of al-Andalus, Al-Jazīra al-Khaḍrā' had been the link between the province and the rest of the Muslim west; in fact, Ibn al-Khațib calls it "the gate of al-Andalus" (bāb al-Andalus). ${ }^{47}$ Its loss contributed to the isolation of the last Muslim possessions in Iberia, and cut off the route for assistance arriving from the Maghrib by sea, though in 744/1344, Yūsuf I did obtain a ten-year truce from Alphonse of Castile after the fall of al-Jazīra al-Khaḍrā'. Nevertheless, danger continued to menace the Nașrid state and its possessions. The Khatrat al-tayf (748/1347) speaks of the permanence of conflict and the anxiety created among the populations of the borders (especially the inhabitants of Vera) ${ }^{48}$ by frequent Castilian incursions. After the victories mentioned above, the king of Castile breached the treaty, and even menaced Jabal al-Fath (the Strait of Gibraltar); the entire province of al-Andalus, according to Ibn al-Khatịb, very nearly fell into the king's hands. ${ }^{49}$ Alphonse succumbed to the Black Death in 1350; his son and successor, Peter I, agreed a treaty with Yūsuf, whose relationship with the Marinids was decaying. ${ }^{50}$

45 Ibn al-Khațīb writes of Alphonse XI of Castile: awqa'a bi-l-musliminn al-waqĩ'a al-'uzmā bi-Tarîf ("He inflicted upon the Muslims the great defeat of Tarīf"), al-Lamha albadriyya, 133 .

46 Wa laqiyat ayyāmuhu shidda li-tamalluk al-'adūw Qal'at Yaḥ̦ub wa-l-Jazīra al-khaḍā̄', Ibn al-Khațīb, A'māl al-A'àm, 265, see also al-Lamḥa al-badriyya, 135 .

47 Ibn al-Khațīb, al-Lamha al-badriyya, 135 .

48 Baldatun 'aduwwuhā muta'aqqib wa sākinuhā khāì mutaraqqib, Ibn al-Khațīb, Khațrat al-țayf, 44, and Dejugnat, "La mer, miroir de la légitimité", op. cit.

49 Ibn al-Khațīb, al-Lamḥa al-badriyya, 133. The Nașrid was twice to call on the Marīnīd Abū 'Inān for help in 75o/1349, notably for Jabal al-Fatḥ and the town of Runda; Ibn al-Khațīb, Rayhānat al-kuttāb, 1:359-365.

$5^{\circ} \quad$ For more on these events, see Latham, "Nașrides", 1025-6. 
A 33-verse poem precedes the prose section of the letter. These verses express the longing of the author for the places of pilgrimage from which he is so distant: the Holy Places of the Hijāz and the sanctuary of Mecca, especially the well of Zamzam and al-Ḥațìm, also called Hijr Ismā̄il, ,1 $^{1}$ with which he literally feels at one ( fa-zamzamuhu dam`` wa-jismı̄ hațimuhu: "its Zamzam is my tears, and my body its Hațīm"). He speaks of his ardent desire to visit the Prophet, to whom he addresses his supplications. Other themes include the Prophet's light, his ontological primordiality, and his role in cosmogenesis, as well as the pre-eminence of the Prophet above other envoys, and the excellence of his character. Then the poem addresses the Prophetic heritage of al-Hajjāj (wa lìyā rasūl Allāh fika wirāthatun), and his genealogy (nisba), which goes back to the Anșār of the Khazraj. ${ }^{52}$ This heritage is also recalled in the prose section of the letter. After this, Ibn al-Khatịb denounces the factors that keep the Nașrid sultan away from the Prophet's tomb, in particular the war waged by the Kingdom of Castile, against whom the Sultan is leading jihād in the face of a much more powerful enemy (ummatan hiya l-bahruyu'yi amrahā man yarümuhu), thus following in the Prophet's footsteps ( $f \imath$ sabilika). This theme will also be developed and amplified in the prose section of the letter; had it not been for the protection afforded by the Prophet, qualified as "refuge for mankind" (malja' al-warā), the reserved territories would have been frightened, and the protected dependencies violated (la-rīa himāhu wa-stubihha harimuhu $\left.u^{53}\right)$. After this the author begs the Prophet not to snap the cord that

51 A small semi-circular wall north of the Ka ba; tradition has it that it was there that the Prophet lay sleeping the night that Gabriel came to find him for his nocturnal voyage; see Lings, Le Prophète Muhammad, 171.

$5^{2}$ Anșār: "The 'Auxiliaries' is the usual designation for those inhabitants of Medina who supported Muhammad; this distinguishes them from his Meccan partisans, the Muhạāirūn or 'emigrants'. After the conversion en masse of the Arabs to Islam, the former name, Banū Qayla, which referred to both al-Aws and al-Khazradj, fell from use, being replaced by Anșār (singulative Anșārī) (see Qurān, IX, 100-1, 117-18). Thus was the memory of the first services rendered to Islam by the Medinese honourably perpetuated. Anșār is probably the plural of nașir. The Khazraj are one of the two principal tribes of Medina; along with the al-Aws [q.v.], they constitute the Banū Qayla of the pre-Islamic period and the Anșār [q.v.] or auxiliaries (of Muḥammad) under Islam"; see Montgomery Watt, "al-Anșār".

Originally, during pre-Islamic times, the himā was pasture reserved for the nobles of the tribe. The Prophet and the first Caliphs used the word to refer to reserving the use of certain pastures for the mounts of the Muslim armies, the camels acquired for the Treasury, and the small herds of the poorer Muslims (Chelhod, cited in 'Akkām, "Des fondements de la propriété", 30). The notion applies to all land whose use is reserved; the same is true of the harim, that can also mean the "dependencies of a location" over which rights of 
binds them together, and returns to the themes of his longing and his distance from the Prophet's tomb. Adding a mention of all the complaints and anxieties with which his missive has been entrusted (wakkaltu biha hammì), he pleads with its addressee not to forget him and, finally, ends his poem with the prayer on the Prophet.

Addressed directly to the Prophet: "To God's (al-Haqq) envoy, to the totality of all creatures (al-khalq), to the cloud of mercy (ghamamm al-rahma)", the prose section of the letter will develop and amplify the ideas of the poem, many themes of which also occur in other letters of the same type that share a structure with Ibn al-Khațīb's epistle, such as the Qāḍī 'Iyāḍ's risāla of a few centuries before, or that of Ibn Abī l-Khișāl, in both of which the first paragraph is devoted to their addressee (ilā rasül al-Haqq, etc.) and to an evocation of his sublime traits and the signs of his elect status. After this long paragraph addressed to the letter's recipient, the Prophet Muhammad, the sender presents himself. Here again the structure is the same as in older letters, and even the phrases used resemble each other strongly; this section of Ibn al-Khațî's letter particularly resembles that of Ibn Abī l-Khișāl. ${ }^{54}$ After this the author gives the reasons for having composed the letter, detailing his yearning, compunction and sorrow at not being able to perform the ziyara at the Prophet's holy tomb (turbatika ${ }^{55}$ al-muqaddasat al-laḥd). Once again, Ibn al-Khațīb is clearly inspired by his predecessor Ibn Abī l-Khișāl, ${ }^{56}$ notably in his mention of al-mashähid wa al-ma'āhid, places that were once familiar to the Prophet, sanctified by his presence and visited by pilgrims: he praises Mecca and Medina, laden with the Prophet's sacred history, where revelation came down upon him. The author then describes the reasons that prevent him from undertaking a pilgrimage to the Holy Places: the enemy already mentioned in the preceding poem. Here the letter takes on an epic flavour. After this, the author writes of the ziyāra ritual itself, tasking the letter with accomplishing it in his place; then he addresses God through the mediation of the Prophet, exalting his election by God and his dignity. This once again resembles the genres of khașẳiṣ (the Prophet's particular traits) and shamāill (the physical and moral

usage apply. These are therefore common lands, or land reserved for the use of the village community. For more on the legal status of real estate in Muslim law, see Lagardère, "Terres communes et droits d'usage" 43-54.

54 See Maqqaīi, Azhār al-riyāẹ, 4:23-4.

55 Ibn al-Khațīb, Rayhānat al-kuttāb, 1:6o; Maqqarī, Azhār al-riyāẹ, 4:41; and Qalqashandī, Șubh al-A'shā, 6:473. Maqqarī, in, Nafh al-țīb, 6:357 gives turbika: literally the earth; turbat signifies mausoleum only by metonymy; the lahd is the sloping part of the tomb in which the body lies, Ibn Manẓūr, Lisān, 13:176-77.

56 Maqqarī, Azhār al-riyāụ, 4:25. 
characteristics of the Prophet). The author, writing in the name of Abū l-Hajjāj, then details the latter's genealogy, going back as far as Sa'd b. 'Ubāda, the oldest member of the Prophet's Anșār, begging the Prophet to take account of this noble descent so that even if Abū l-Ḥjjāj had no praiseworthy actions to his credit, [the purity of] his intentions would count in his favour. In the course of this plea the recent and current political and military situations dominate. The letter ends with the tas liya, prayer of blessings on the Prophet, on his allies (ahzābika), on those close to him (Álika), ${ }^{57}$ and on the two companions buried near him, as well as on his cousin and son-in-law 'Alī.58

Here we will attempt to tease out a number of themes that are developed in the letter, notably the representation of the Prophet Muhammad, his presence, and the relationship with him.

\subsection{The Supra-Terrestrial and Sacred Person of the Prophet}

The universal nature of Muhammad's message (with reference to Q 34:28) is underlined right from the first lines of the letter: "he is God's envoy to all creatures" (rasūl al-Haqq ilä käffat al-khalq), as is his apostolate's function of mercy (wa ghamām al-rahma); he is the seal of prophets, and the author exalts his ontological primacy ("He was a prophet when Adam was between water and mud" (man wajabat lahu al-nubūwa wa Ādam bayna al-țin wa-al-mā) ${ }^{59}$ his status as intercessor for "sinners laden with faults" (shafi $\iota^{\imath}$ arbāb al-dhunūb), and his function as mediator between mankind and God the Omniscient (al-wasila ilä 'Allām al-ghuyūb). ${ }^{60}$ As in the traditions of shamā'il and khașầiș al-nubuwwa, the author lists the attributes and functions of the Prophet, concentrating on the economy of salvation; he also enumerates the signs of his elect status and of his perfection. He evokes Muhammad's role in cosmogenesis, his nocturnal voyage and celestial ascension, and his primordial light that is the origin of all light (man al-anwāru min 'unșuri nürihi mustamadda). Following the Mawlidiyyyāt tradition this time, Ibn al-Khatịb writes of the luminous and miraculous signs that accompanied the Prophet's birth: "At his

57 On the interpretation of the word $\bar{A} l$, see Addas, La Maison muhammadienne, 144-54.

$5^{8}$ Maqqarī, Naf̣ al-țīb, 6:354-6o.

59 For more on the hadìth "kuntu nabiyyan ..." ("I was a prophet when Adam was between water and mud"), see Addas, La Maison muhammadienne, 47-55.

6o $\quad$ Maqqarī, Naf̣̣ al-țīb, 6:356. 
birth the fortresses and palaces of Syria were illuminated" (wa aḍàat li-mülādihi mașāniu al-Shām wa qușūruhu); he also recounts the Prophet's miracles (dhü $a l-m u$ jizzāt $){ }^{61}$

Lord, You have made of him the first of prophets in spirit and the last in body; You have granted him the banner of praise; Adam and all his descendance walk in his unfolding shadow; You granted to his community the earth that You folded for him [so that he saw its easts and its wests]. ${ }^{62}$

This representation of the Prophet is very close to that seen in the letter attributed to Qāḍi Iyāạ, and it indicates the existence of a "prophetic culture" that was fairly widespread in scholarly and Sufi circles in the Maghrib, as in other regions of the Muslim world.

\subsection{The Shadow That Covers All of His Community}

The prophet is the shadow that covers all of his community (al-zill al-khaffāq 'alā ummatihi). ${ }^{63}$ This protective aspect of the Prophet is praised particularly strongly in these times of disturbances and war, circumstances that are evident throughout Ibn al-Khațîb's letter. Ibn al-Khațīb underlines the superior forces of the enemies of the little Nașrid state; it is under siege from all sides, its strength cannot be compared in extent or numbers to the massed contingents of its adversaries ('adūw tatakāthafu afwājuhu): the dust from their horses' hooves masks the sun's light at its zenith (wa yahjubu al-shamsa inda al-zahirati 'ajäjuhu). Despite the modesty of their means, ${ }^{64}$ the Muslim combatants display magnanimity in the face of troops that the author compares to the armies of Caesar and Kisrā: "They exchange blow for blow with troops as numerous as those of Caesar or of Khosrow" (wa yuqāriūna wa hum al-fiatu al-qalìla ${ }^{65}$ jumü'an ka-jumū' Qayșar wa Kisrā). Thanks to the Prophet's support, these believers (al-mu'minün) arm themselves with patience; their complete

61 Maqqaīi, Naf̣̂ al-țīb, 6:356-7.

62 Maqqarī, Naf̣ al-țīb, 6:359; on the final phrase, see the hadīth: "Inna Alläh zawā lì l-ard fa-ra’aytu mashāriqahā wa maghāribahā", "Allāh folded the earth so much for me that I saw its easts and its wests. The kingdom of my community will reach as far as the earth was flooded for me" in Muslim, Saḥịh, Kitāb al-fitan wa-ashrāt al-Sā́a, hadīth $\mathrm{n}^{\circ} 2889$.

63 Maqqarī, Naf̣̣ al-țīb, 6:356.

64 This theme has virtually become a literary motif, found throughout eastern historiography, see Arié, "Les relations diplomatiques", 98-9.

65 Al-fía al-qalïla refers to Q 2:249: the 313 companions of Saul who held fast in the face of Goliath's army, the number of whom anticipates that of the Companions of Badr: "How many a little company hath overcome a mighty host by Allah's leave! - Allah is with the 
surrender to God and the Prophet, from whose approbation they draw their strength, is their armour (labüsuhum); they have exchanged this earthly existence for the final life. ${ }^{66}$ This quasi-epic invocation of battles between Muslim armies and their enemies ${ }^{67}$ awakens echoes of the battle of Badr, ${ }^{68}$ with the actions of the Prophet and his Companions in the face of the Qurayshis, and also of the wars that later pitted the young Muslim state against the Byzantine and Sassanid Empires. Through references to events that are foundational for the entire community, collective memory is mobilised in the present, not only by invoking the symbolic power of those events, but also by the quest for a mimesis of those excellent men whose vigorous faith and abandonment to God brought them victory.

Indeed, is it not surprising that among the grievances addressed to the Prophet, the ongoing political and military situation in al-Andalus constitutes a sort of recurring leitmotif, emphasising and exalting his protective functions:

Do not forget me, nor the inhabitants of this isle that was conquered by the sword of your word (al-muftataha bi-sayfi kalimatika), ${ }^{69}$ by the best men of your community; we are but a trust beneath one of your locks; may the face of your Lord preserve us from neglecting [your rights]; we breathe the perfume carried on the breeze of your protection and await your agreement, through which we will repel a despotic and oppressive enemy who, through his harassment, has attained his aim; the constant trials to which we are exposed have wearied our historians; and the sea has silenced all our cries for help (wa l-bahr qad așmata man istașrakha) [...] The enemy is resolute and the ally ${ }^{70}$ is deficient (al-'aduww muhalliq wa l-wali muqașșir); ${ }^{71}$ in the name of the consideration you possess [from

steadfast - (kam min fiatin qalìlatin ghalabat fiatan kathīratan bi-idhni llāh wa llāh ma'a l-șābirīn)" trans. Pickthall, Holy Qur'ān, 45.

66 Maqqarī, Naf̣ al-țīb, 6:358.

67 This evocation is nevertheless much less extensive than the description that takes up several pages in the letter written in the name of Abū l-Ḥajjāj's son and successor, al-Ghanī billāh; see above.

68 For more on this battle, see Lings, Le prophète Muhammad, 243-253.

69 For more on the Arab conquest of Spain, see Guichard, "La conquête arabe de l'Espagne", 377-389; on the existence of Arab scholars in al-Andalus during the second/eighth century, often alongside early military settlements, and on the Islamisation of al-Andalus in general, especially the Algarve, see Marín, "À l'extrémité de l'Islam médiéval", 361-381.

70 Walı is here intended to mean the ally from whom one awaits aid; for more on the vast semantic field covered by the root w.l.y., see Ibn Manzūur, Lisān, 15:281-5.

71 Apparently Ibn al-Khațib is playing on the two senses of hallaqa and qașsara: the first meaning that comes to mind is that of the bird of prey circling in the sky (hallaqa) before 
God], we reject [a yoke] that overwhelms our forces, and thanks to your care we tend those whose religion has weakened, that they might recover [their belief]; do not abandon us, do not neglect us; invoke your Lord for us: "Our Lord! Impose not on us that which we have not the strength to bear" ( $Q$ 2:286). Your protection suffices to preserve the safety of groups that belong to your community; has not your Lord said: "But Allah would not punish them while thou wast with them" (Q 8:33)? ${ }^{72}$

After having initially spoken of the great feats of arms accomplished by Muslim forces under the Nașrid banner (since jihād remains one of the fundamental duties of a sovereign, and the seal of his legitimacy), the admission of impotence in the final plea, and the Sultan's confession that he is not up to accomplishing this duty in the defence of Islam, read more like a common and current motif in prayers on the Prophet, not necessarily to be taken literally. In any case, such avowals would reinforce the image of a pious, magnanimous, and valiant ruler, who humbly recognises his own limitations, even his failures, and who faces overwhelming forces: an external enemy and the wavering faith of his own people. All of these elements would be likely to inspire sympathy and help from Islam - such help as was cruelly lacking for the Nașrid.

With regard to the theme of the presence of the Prophet, the verse Ibn al-Khațib chooses to quote is significant: the bonds between the Prophet and his community have not been broken by the former's death and disappearance from the stage of history; he lives on in and through his community, and

diving onto prey that is powerless (muqașsir) or not doing enough to save itself. The second meaning relates to a well-known episode in the sira; according to Abrahamic tradition, pilgrims who had consecrated animals to sacrifice were obliged to perform the sacrifice within the sacred territories, and then to shave their heads. After the signing of the treaty of Hudaybiyya with the Qurayshis, which prevented believers from accomplishing the pilgrimage until the following year, the Prophet commanded them to sacrifice their animals and shave their heads. The believers were disappointed at having to skip the pilgrimage for a year and break the Abrahamic ritual, and did not obey. Later, they did follow the Prophet's example - except for a few, who only cut a few strands of their hair (qașsarū). The Prophet is said to have invoked God: "O Allāh, have mercy on those who have themselves shaved." (Allāhumma irham al-muhalliqīn); He repeated this $d u^{\prime} \bar{a}^{\prime}$ three times, despite the protestations of those who had only cut a few strands of hair; on the fourth repetition he added, "and on those who clip their hair!" Later, when he was asked why he had initially invoked pity only for the muhalliqin, he replied: "because they did not doubt!" Ibn al-Khațîb, in using these two words, almost certainly wants to refer to this episode and say that the enemy is resolute and the Muslims are in a state of doubt; for more on this episode in the sira, see Lings, Le prophète Muhammad, 416-7.

72 Maqqarī, Naf̣h al-țīb, 6:36o. For English translations of verses, see Pickthall, Holy Qur'ān, 54 and 200. 
his bodily and/or his spiritual heirs, in particular, perpetuate the Prophetic charisma. ${ }^{73}$ According to one exegesis of the verse cited (Q 8:33), and the one that follows it, "wa mā kāna mu'adhdhibahum wa hum yastaghfirūn" (Nor will He punish them while they seek forgiveness), ${ }^{74}$ the Prophet said, on the subject of these verses and the two conditions that preserve Muslims ${ }^{75}$ from God's punishment, "Allah sent down two guarantees of safety for the benefit of my Umma (anzala Allāh 'alayya amānayn li-ummatī). So when I pass, I leave seeking forgiveness among them until the Day of Resurrection." ${ }^{76}$ From this point we can address the genuinely eschatological dimension of this letter.

\subsection{Tawassul in This World and Intercession in the Hereafter}

Tawassul (the invocation of God through the mediation of the Prophet) is very present in this letter, confirming what we have observed in other written production: the istighätha (call for succour) addressed to the Prophet is required as much for "worldly" issues as for eschatological reasons. The Prophet's mediation may be sought in order to confront community enemies whose power is crushingly superior, to whip up tired and sore souls and wake them from their lethargy, or to "heal sick hearts" (isn't he called "the doctor of hearts", tabib $a d w \bar{a}$ ' al-qulūb?); however, he can also be asked to intercede for the Day of Counting, of which this letter shows great awareness, evoking certain episodes from the Last Judgement as well as the eschatological figure of the Prophet; the letter contains no fewer than eight occurrences of eschatological themes.

Initially these motifs appear with regard to the collective: the Prophet is called shafí arbāb al-dhunüb (the intercessor for human beings weighed down with sins); he carries the unfolded banner on the Day of Resurrection (șāhib al-liwāa al-manshüryawm al-nushür); he is the answered intercessor - literally the one whose intercession is received - on the Day of Facing God (al-shafi $i^{\top}$ al-mushaffa yawma l-Ard); ${ }^{77}$ his is the most certain assistance on the Day of Great Fear (al-mafza' al-amna' yawm al-faza' al-akbar). All of these episodes (the resurrection, the great gathering al-hashr, the presentation in ranks before God, yawm al-Ard) are part of the "events" of the Last Judgement, affecting the

\footnotetext{
73 See Gril, "Prophétie et charisme en islam", 27-36.

74 Trans. Pickthall, Holy Qurāan, 200.

75 And not only the Meccan Qurayshis who, according to the asbāb al-nuzūl (context of revelation) were the original addressees: see Ibn Kathīr, Tafsirr, 2:372.

76 Ibn Kathīr, Tafsìr, 2:372.

77 Al-ard, on the Day of Last Judgement, also refers to the idea of an examination of man by God, as in Q 18:48, "And they are set before thy Lord in ranks" (trans. Pickthall, Holy Qur'ān, 331) (wa 'urị̣̄u 'alā Rabbika șaffan).
} 
collective fate of all the dead. ${ }^{78}$ Another element is the calling and appearance of individuals before God, to be questioned (al-musāala or al-su'a $l$ ) and have their actions weighed in the balance (al-mizañn) according to the books or registers (al-dawāwin) in which the sins and merits of each are noted $;^{79}$ all of these episodes relate to the fate of the individual. However, according to a Prophetic tradition, from the moment of the opening of each one book (and according to whether the human being receives his book into his right or his left hand, Q 17:71), and when he is crossing the bridge (al-șirāt), each human being is entirely alone. At this stage, the Prophet cannot help even his own People. ${ }^{80}$ Nevertheless, the letter solicits the intercession of the Prophet for the Nașrid: "My God, accord me the assistance of his intercession on the day I take up my book (Tadāraknī bi-shafā'atihi yawma akhdhi kitābī)", ${ }^{81}$ referring to Q 17:13-14 ("and We shall bring forth for him on the Day of Resurrection a book which he will find wide open. Read thy Book. Thy soul sufficeth as reckoner against thee this day"). His prestigious descent from the Anșār via his ancestor Sa'd b. 'Ubāda, mentioned a few lines further down, is what gives the Nașrīd sultan this right and this privilege with the Prophet: "By my genealogy, which goes back to the eldest of your Auxiliaries, Sacd [b. 'Ubāda], I benefit from recourse to privileged and manifest favour from you ( fa-lì bi-ntisābi ila Sa'd, 'amìdi anșārika, maziyya wa wasila athìra khafìya)". 82 Even the terms used to present the Nașrid bear witness to this genuinely eschatological dimension: 'atìq shafä'atihi, the one who is freed [from fire] through the Prophet's intercession - this refers to a tradition from the Sihăh (canonical collections), ${ }^{83}$ according to which at the Last Judgement all the prophets from Adam onwards will recuse themselves from intercession, and it will revert to Muhammad. By virtue of this tradition, the Prophet obtains from God the ability to deliver sinners "in whose hearts there is faith even to the lightest, lightest mustard seed" from the fires of Gehenna.

\footnotetext{
78 Amri, Les saints en islam, $53^{-} 56$.

79 Amri, Les saints en islam, 55 .

8 o Ghazālī, Ihya $\bar{a}^{3}$, vol. vi, fasc. 16:43, cited in Amri, Les saints en islam, 55-6.

81 Maqqarī, Nafh al țīib, 6:359.

82 On the etymology of the word khafã: to manifest, make apparent or extract (khafaytu: ažhartu), see Ibn Manz̄ūr, Lisān, 5:116-8.

83 Notably for Bukhārī, Șahịh, Kitāb al-tawhìd, 9:149-150 and 160-161 (these hadīths are, respectively, numbers 7440 and 7510 ).
} 


\subsection{Prophetic Heritage and Its Mobilisation}

Without going into too much detail about Nașrid genealogy, let us just remain aware that genealogists and chroniclers, including Ibn al-Khațîb, ${ }^{84}$ ascribe to them a descent from Qays b. Sa'd b. 'Ubāda al-Anșārī al-Khazrajī al-Sā'idī al-Madanī, the chief of the Khazraj (sayyid al-Anșār) in Yathrib, to whom al-Dhahabi attributes the titles of Sayyid and sharîf. ${ }^{85}$ The letter underlines this prophetic heritage twice. ${ }^{86}$ There is an abundant literature on the merits of the Anșār (fadāàl al-Anșār), who are mentioned in the Qurān (for example, Q 8:72, 8:74 and 59:9) and in traditions. ${ }^{87}$ The Qurān and the hadīth that followed both praised the merits of the Anșār, 88 "the Auxiliaries of Allah and His Envoy (Anșār Allāh wa Anșār rasūlihi):" they are "those who took in [those who believed and left their homes and strove for the cause of Allah] and helped them", and who, along with the Émigrés, fought in the path of God, "these are the believers in truth" (Q 8:74), an idea that is re-stated in a hadith we have already mentioned; 89 a variant of this hadith reported by Anas b. Mālik has the Prophet saying: "The very sign of faith (Āyat al-imān) is love for the Anșār; to detest them is a sign of hypocrisy." When, in the Qurān, the Banū Nadīir depart and the Prophet distributes their lands to the Émigrés, the selfless friendship of the Anșār for the Émigrés is praised: "Who love those who flee unto them for refuge and find in their breasts no need for that which hath been given

84 Ibn al-Khațib, al-Lamḥa al-badriyya, 57 .

85 Dhahabī, Siyar, 1:270-9. According to the sir $r$, when the Prophet went on an expedition the first person designated among his Companions to take on the responsibility for Medina in his absence was the Khazrajī leader, Sa'd b. 'Ubāda (Lings, Le Prophète Muhammad, 226); on the day of the conquest of Mecca the Prophet had given him his standard; this was carried by his son Qays (ibid. 488). After the death of the Prophet, the Anșār (both Aws and Khazraj) who were in the Saqĩfat Banū Sāiida, a clan directed by Sacd, were about to swear allegiance to Sa'd; the latter refused his allegiance to Abū Bakr, and again, later, to the second Caliph, 'Umar; he left Medina for Syria, where he died in Hawrān in 14/635 or 16/637, Lings, Le Prophète Muhammad, 56o-1 and Dhahabî, Siyar, 1:277 and 279.

86 If we look at both the poem and the prose letter that follows it.

87 See the hadìth attributed to the Prophet about the Anșār and reported by Bukhārī in his Șah̄ḥ, Bāb ḥubb al-Anșār, 5:39-40, according to Al-Barā' b. 'Āzib: "No one loves them except a believer and no one hates them except a hypocrite. Allah loves whoever loves them and hates whoever hates them."

88 See the book composed by the Andalusian qāậ̄ Abū Bakr 'Atīq b. al-Firā’ al-Ghassānī al-Andalusī (d. 698/1298), Nuzhat al-abșār fífaḍāil al-Anșār.

89 Indeed, the canonical collections in the Kitāb al-ìmān (the Book of faith), devote a section $(b \bar{a} b)$ to the Anșār and the love that is due to them as an article of faith; Muslim, Șahīh, Kitāb al-ìmān, Bāb al-dalīl 'alā anna ḥubb al-Anșār wa 'Al̄̄ min al-īmān; Bukhārī, in his Șaḥịh, Kitāb al-īmān, Bāb 'alāmat al-īmān ḥubb al-Anșār. Elsewhere the latter devotes a section to the Anșār "titles of glory": Bāb Manāqib al-Anșār, and to the merits of the role they played (Bāb fậl dawr al-Anșār). 
them, but prefer [them] above themselves though poverty become their lot" (Q 59:9). After the battle of Hunayn, the Auxiliaries who resented their modest booty in comparison to that lavished by the Prophet on Qurayshi chiefs and other tribes (in order to win them over to Islam) are said, according to a tradition recorded in the canonical collections, to have been comforted thus: "Is it not enough for you, Oh Auxiliaries, while these people take away sheep and camels, that you take God's Envoy with you to your homes? If every human except the Auxiliaries took one path and the Auxiliaries took another, I would take the Auxiliaries' path. May God have mercy on the Auxiliaries, on their sons and the sons of their sons!"90 According to another, clearly eschatological, hadith, which is considered authentic, the Prophet addressed the Anșār as follows: "Arm yourselves with patience in order to meet me again at the $\operatorname{Basin}($ al-hawd $) .{ }^{\prime \prime 1}$

Ibn al-Khațib's reference to his monarch's Prophetic heritage would be inherently supportive of the claims of the Nașrids, especially Yūsuf, to the title of Caliph, and affirm the latter's religious and political authority; ${ }^{92}$ the text of the inscription on the funeral stele of Sultan Yüsuf, which was also written by Ibn al-Khațîb, assigns to his grandfather, Abū Sa'd Faraj b. Ismāîl ibn Nașr, the

9o This tradition is considered authentic; one version is to be found in Bukhārī, Șahịh, 5:38. Another hadīth is also attributed to the Prophet: "May God forgive the Anșār, their sons and the sons of their sons", Allāhumma ighfir li-al-Anșār wa abnā' al-Anșār wa abnā̄ abnā"

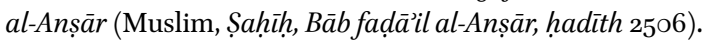

91 Bukhārī, Saḥị̣, Bāb Manāqib al-Anșārr, 5:41, Bāb qawl al-nabī [...] li-al-Anșār : iṣbirū ḥattā talqawnì alà al-hawd.

92 For more on this claim, see the above-cited article by Dejugnat: "María-Jesús Rubiera has recently demonstrated that the Nașrids laid claim to the title of Caliph. Yūsuf I does indeed have a Caliphian honorific name (laqab), with bi-lläh, Mu'ayyad bi-lläh, and his official pangyrists, Ibn al-Jayyāb and Ibn al-Khațīb, call him Caliph with a noticeable frequency, although they never accord him the official titles of 'Lieutenant of God's messenger' (khalīfat rasül Alläh) or 'Commander of the faithful' (amìr al-Mu'mininn) [only referring to him as Amìr al-Musliminn]. [...] According to María-Jesús Rubiera, the Nașrids lay claim to the Caliphate from the time of Ismā'il I (r. 1314-1325). In any case, the use of this claim was mostly internal, or even private, in that it would not have done to rub the Marinids the wrong way, since they were a vital source of support for the kingdom in the face of the Christians, and they also laid claim to the Caliphal title."; see also Rubiera Mata, "El Califato Nazārī", 293-305. Let us also recall that before the Marīnids and Nașrids, one of the Hafșids of Tunis, al-Mustanșir bi-llāh (r. 647-675/1249-1277), the son of the dynasty's founder Emir Abū Zakariyā', had pronounced himself Caliph (he took on the Caliphal name of the Abbasid Abū Ja'far al-Manșūr, d. 640/1242) and received his Hijāz bay'a as brought by the Sufi Ibn Sab'in in 655/1257, and from al-Andalus; Tunis became, for a time, the capital of the Caliphate; "such competition between capitals to occupy the centre of the world" (Dejugnat "La mer, miroir de la légitimité") would be extended to Fez and Granada. 
attribute of Kabìr al-khiläfa al-Nașriyya (the Senior of the Nașrid Caliphate). ${ }^{93}$ The claim to the title of Caliph assumes full significance when seen from an eschatological perspective and in the context of a war with Christian kingdoms and jihād at the frontiers of the Dār al-Islam, which it is a sovereign's duty to pursue. By virtue of the above-cited traditions, such noble descent provides the assurance of salvation; on the Sultan's funerary stele Ibn al-Khațib also invokes God, that He might "welcome him to Paradise by the side of his ancestor Sacd b. 'Ubāda [...] and resuscitate him with his forefathers, the Anșār, thanks to whom He brought about the triumph of the faith and saved them from the Fire". ${ }^{94}$

\subsection{The Living Presence of the Prophet and the Intimate Love Shared with Him}

This letter also merits attention to its quasi-private dimension, to which the epistolary genre lends itself. Here our author gives free reign to an outpouring [of love] and describes an intimate relationship with the Prophet Muhammad, one that has echoes of Muhammad's relationship with his Companions. ${ }^{95}$ This participation in the Prophet's life, and this desire for communion with the Prophet, also appears in the evocation of the most intimate part of the spiritual and divine experience of the Envoy himself, his conversations with the Archangel Gabriel. Before stating the nominal identity of the letter's sender (Sultan Abū l-Ḥajjāj Yūsuf), Ibn al-Khațīb expresses a series of attitudes, credos, ways of being, and above all facts and gestures, drawn from daily life, that are signs not only of the living presence of the Prophet, but also of this quasiintimate relationship with him, a relationship in which love plays a big part:

On behalf of the one [Sultan Yūsuf] who is freed [from the fire] thanks to his [the Prophet's] intercession ('atīq shafä'atihi), slave of obedience [to the Prophet's prescriptions] ('abd țā'atihi), firmly attached to him; from the one who believes in God and then in him, find in his invocation a remedy for his suffering (al-mustashfí bi-dhikrihi kullamā ta'allama), bring down the divine blessings on him each time he speaks, and, if he [the Prophet] is mentioned in front of him [Sultan Yūsuf], he pictures his appearance, among his Companions and the People of his House. If a scented breeze blows, he [Sultan Yūsuf] thinks it the scent of his [the Prophet's] friendship, and if he hears the call to prayer he remembers the

93 Ibn al-Khațīb, al-Lamḥa al-badriyya, 136.

94 Ibn al-Khațīb, al-Lamha al-badriyya, 136.

95 Gril, "Comme s'il y avait des oiseaux sur leur tête" 25-40. 
voice of his muezzin [Bilāl], and if the Qurān is recited [he] pictures Jibrīl seeking him [the Prophet] in the places he was wont to go, or that were familiar to him (bayna maáahidihi wa khilālihi); he [Yūsuf] embraces the earth [that shelters the Prophet's remains] (läthim turbihi) ${ }^{96}$ and hopes for his proximity (mu'ammil qurbihi); he is a hostage to obedience [to the Prophet's injunctions] and to his love [for the Prophet] (rahī țấatihi wa hubbihi), and invokes divine consent by his mediation (al-mutawassil bihi ilā rị̣a llāh Rabbihi), Yūsuf b. Ismā̄̄il b. Nașr. ${ }^{97}$

Love for the Prophet is very present in this letter, on the individual and the collective level. Love for his person "replaces breath for souls" (wa jarä fi l-nufüs majrā l-anfäs hubbuhu), ${ }^{98}$ and is also consubstantial with Muhammad's community; this love itself is also inscribed in a soteriological finality, as expressed in the terms of this invocation addressed to God in the Nașrīd's name:

You brought me forth in his umma whose substance and primary nature are love [of the Prophet] (al-majbūla 'alä ḥubbihil-mafțūra); You increased my desire to visit the places that are sanctified by his presence and You gave my tongue the task of praying on him (wa wakkalta lisānī bi-l-șalāt 'alayhi), and my heart a yearning for his ziyāra [...]. Do not break the cord that attaches me to him, do not deprive me of the rewards of his love, and grant me his intercession on the Day I receive my book. ${ }^{99}$

In a similar way, the familial metaphors very often used about the Prophet surface here, too, notably his representation as a father whose compassion and mercy would "melt the souls of the fathers in commiseration" (law kāna li-l-äbāi rahmatu qalbihi, dhābat nufüsuhum ishfāqan).100

\subsection{Before the Tomb of the Prophet: Letter and Ziyāra}

"I have mandated it to fly to you on the wings of my ardent desire" (istanabtu ruq'atī hädhihi li-tațīra ilayka min shawqī bi-janāhin khāfiqin), writes Ibn al-Khațīb in the name of his king. He has this missive make all the gestures

${ }_{96}$ See this verse from the Burda by al-Būṣinīi, "no perfume is sweeter than the earth that shelters his remains; happy is he who breaths its odour and rubs his face in it" (lā-țība ya'dilu turban damma a żumahu/țūba li-muntashiqin minhu wa multathimi), this is the equivalent of embracing it, lathima, commentators add: Ibn 'Āshūr, Shifä’ al-qalb al-jarīh, 163; for another commentary on this verse, see Ibn Marzūq, Ižhār șidq al-mawwadda, 1:288-91.

97 Maqqarī, Naf̣ al-țīb, 6:357.

98 Maqqaī, Naf̣ al-țīb, 6:356.

99 Or book drawing up the accounts on the Day of Judgement; Maqqarī, Naf̣ al-țīb, 6:359.

100 Maqqaī, Nafh al-țīb, 6:356. 
of humility and devotion he would himself have made on a ziyāra, gestures laden with a powerful emotional burden and with a quest for a "physical" contact; they express both veneration and love: "rubbing one's cheek against" ( $w a$ tu'affiru al-khadda fi turbika wa tumarrigh) the earth sheltering the Prophet's remains. ${ }^{101}$ He tasks the letter with transmitting his grievances ( $f a$-tu'addì 'an 'abdika wa tuballigh), ${ }^{102}$ reciting a series of invocations addressed directly to the Prophet, in his roles as "succour for his community" (ghiyāth al-umma) and "cloud of mercy" (wa ghamām al-rahma), that the Prophet might pity the writer's ghurba (exile) and inqița $\bar{c}^{c}$ (isolation); ${ }^{103}$ if the first word (ghurba) seems once more to refer to the origins of the Nașrid, that go back to the Anșärs of Medina, the second (inqița $\bar{c}^{\top}$ ), following and emphasising the word ghurba, signifies the rupture of the sender's ties with his people, and his isolation. ${ }^{104} \mathrm{He}$ also asks the Prophet to approve this delegation or "mandating" of the letter ( qābil bi-l-qabūl niyābatī).

Love and profound veneration for the Prophet are largely considered to be unvarying; however, letters addressed to him may rightly be seen as an expression of the specifically Muhammadian devotion that developed from the sixth/twelfth century, and became widespread during the seventh/thirteenth century; the profoundly uncertain circumstances in the Sultanate of Granada in the eighth/fourteenth century served to emphasise the Prophetic figure of succour, protection, and intercession in difficult times. When Ibn al-Khațib was writing, such letters addressed to the Prophet from this part of the Muslim world were, through their common themes and even in the organisation of their discourse, already a veritable genre, one from which our author drew much inspiration and that, specifics aside, remained very consistent.

Yet if we put the letter composed in the name of the Nașrid Yūsuf I back into the context of other missives addressed to the Prophet, just such specifics do appear. Ibn al-Khațîb's epistle was written at a difficult time, in the name of a sovereign who was at war with Christian kingdoms, and while the Muslim side seemed demoralised, weakened by divisions and contradictions. This mood is perceptible in the text of Ibn al-Khațîb's letter, which contains themes that

\footnotetext{
101 Maqqarī, Naf̣ al-țīb, 6:359.

102 Maqqarī, Naf̣ al-țīb, 6:359.

103 Maqqarī, Nafth al-țīb, 6:359.

104 "One says of the stranger in a country that he is cut off from his relations, so is he dissociated from them" (uqția 'an ahlihi iqțā'an fa-huwa muqța'un 'an ahlihi wa munqați'), Ibn Manẓūr, Lisān, 12:140.
} 
are absent in its predecessors; here jihād is simultaneously: an obstacle to the accomplishment of ziyāra at the Prophet's tomb; a destiny that is inscribed in a Prophetic history of which the Sultan is at once the depositary and the heir; a title to glory in the service of Islam and its Prophet - reinforcing the legitimacy of its possessor when he exercises this right - and, finally, an object of istighātha (a request for succour) addressed to the Prophet. What's more, a certain image of the monarch is fashioned here: he is pious, humble and magnanimous; jealous of his territorial sovereignty and of the integrity of the Dār al-Isläm; a worthy continuer of the acts of his pious predecessors, and a king whose love and respect for the Prophet are at the centre of his piety, his daily life, and his hopes. The Prophetic heritage claimed by the author for the Nașrid, especially in a context of jiha $\bar{d}$, reveals the importance that is henceforth accorded to a spiritual or physical link with the Prophet: this will act as a guarantee at once of baraka, of salvation, of legitimacy, and of participation in a sacred history, that of the Prophet and his Companions. This being said, and despite the fact that this letter was composed on behalf of a monarch, the individual and personal dimension that is very present in letters such as those of Qāọī 'Iyāḍ or Ibn al-Jannān is no less important here: Ibn al-Khațīb gives his sensibility and emotions free reign, along with his complaints and his outpourings that are often lyrical and always marked by a tone of great sincerity. One cannot help but think that here, screened by his prince, it is the individual man, Ibn al-Khațīb, who is expressing himself, and thus offering us much insight into his perception of the Prophet's interior reality and the sacredness of his person, as well as into his own love for the Prophet and faith in his assistance here below, and his intercession in the next world. Couldn't one compare these representations, which our author shares with his predecessors, with the manifestations of devotion to the person of the Prophet and to the figure or figures of the Prophet that were in general circulation in the scholarly and Sufi circles of eighth/fourteenth century Granada? All of this is part of what one can henceforth consider to be a genuine and growing "Prophetic culture", nourished by a literature centred on the Prophet that, starting with Qāḍī 'Iyāḍ's

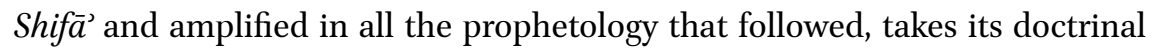
form in the writings of Ibn 'Arabī. This Prophetic culture is profoundly cohesive, crossing social and geographical boundaries and informing the spirituality of mystics, scholars and humble pious people alike. Researchers become accustomed to considering the manifestations of piety, empathy and emotion that this veneration brings forth to be particular to a "popular" Islam, so-called; in fact, these manifestations are common to the masses and the élites.

The interpretation of such letters in the light of the debate concerning Ibn Taymiyya's (d. 728/1328) writings on the ziyāra, the contested authenticity of 
the hadith on the visit to the Prophet's tomb, and the Damascene jurist's opposition to the practice of the istigha atha, ${ }^{105}$ demonstrates that in the Maghrib the ziyāra at the Prophet's tomb, the writing of letters addressed to the Prophet, and the practice of tawassul and istighätha were widespread, among the people as among jurists and Māliki scholars of the best tradition.

\section{Bibliography}

\section{Primary Sources}

Bukhārī M. Saḥ̄ḥ al-Bukhārī, 3 volumes, ajzä’ 1 to 9, Beirut, Dār Ihyāa al-turāth al-'arabī, n. d.

Dhahabī M. Siyar A'lām al-nubalā’’ Beirut, Mu’assasat al-Risāla, 2001.

Fāsī, A. Al-Iqd al-thamin fì tārīkh al-balad al-amìn, ed. F. Sayyid, Beirut, al-Risāla, 1985, vol. 6.

Ghubrīn̄i, A. 'Unwān al-dirāya fì-man 'urifa min al-ulamā’ fì al-mia al-sābía bi-Bijāya, ed. A. Nuwayhiḍ, Beirut, 1979.

Ibn Abī al-Khiṣāl, M. Rasā̉il Ibn Abī al-Khișāl, ed. M. R. Al-Dāya, Damascus, 1988.

Ibn 'Āshūr, M.-T. Shifă’ al-qalb al-jarịh bi-sharh Burdat al-madīh, Tunis, Dār al-Janūb, 2015 .

Ibn Bassām, 'A. Al-Dhakhīra fì mahạsin ahl al-Jazīra, Part II, t. 1, ed. I. 'Abbās, Beirut, Dār al-Thaqāfa, 1997.

Ibn al-Firā' al-Ghassānī al-Andalusī, 'A. Nuzhat al-abșār fí faḍāil al-Anșār, ed. 'A.-R. Marzūq, Riyād, 2004.

Ibn al-Jannān, M. Dīwān Ibn al-Jannān al-Anșārī al-Andalusī, ed. M. M. Bahjat, al-Mawșil, 1990.

Ibn Kathïr Tafsir, Mecca, n.d.

Ibn al-Khațīb, al-Iḥăța fì akhbār Gharnāța, ed. B. Al-Darrājī, Algiers, 2009

Ibn al-Khațīb, Rayhānat al-kuttāb wa nuj'at al-muntāb, ed. M.-'A. Inān, Cairo, 1980.

Ibn al-Khațīb, A'māl al-A'ām, ed. S. Kasrawī, Beirut, Dār al-kutub al-'ilmiyya, n.d.

Ibn al-Khațīb, Khațrat al-țayf fì rihlat al-shitǟ’ wa al-șayf, in A. M. al-Abbādī, ed.

Khatrat al-tayf, Rihlätfial-Maghrib wa al-Andalus 1347-1362, Abu Dhabi, 2003, 31-56. Ibn al-Khațīb, al-Lamha al-badriyya fì al-dawla al-Nașrīya, ed. M. M. Jibrān, Beirut, Dār al-madār al-islāmī, 2009 .

Ibn Manzūur, Lisān al-'Arab, Beirut, Dār Șādir, 2005.

Ibn Marzūq al-Ḥafìd al-Tilimsānī, M. Iz̧hār șidq al-mawadda fì sharh al-Burda, ed.

M. Fallāq, Tlemcen, 2011.

105 A debate that led Subkī (d. 756/1355) to write his Shifä’ al-sīqām fì ziyārat khayr al-anām; Hamidoune, "La pratique de la 'prière sur le Prophète", 54. 
Ibn al-Ṭawwāḥ, M. Sabk al-maqāl li-fakk al-'iqāl, ed. M. M. Jibrān, Beirut, Dār al-Gharb al-islāmī, 1995 .

Maqqarī, A. Azhāral-riyāẹffi akhbār 'Iyāụ, vol. 3, ed. M. Al-Saqqā, I. Al-Abyārī, A. Shalabī, 1st edn. Bayt al-Maghrib, Cairo, 1942 and vol. 4, ed. S. A. Árāb, M. Bin Tāwīt, Rabat, 1978.

Maqqarī, A. Naf̣̣ al-țīb min ghuṣn al-Andalus al-rațīb, ed. I. 'Abbās, Beirut, Dār Șādir, 1968.

Maqrīz̄ì, A. Durr al-'uqūd al-farīda fì tarājim al-A'yān al-mufìda, ed. M. Al-Jalīlī, Beirut, Dār al-Gharb al-islāmī, 2002.

Qalqashandī, A. Șubḥ al-A'shā fì kitābat al-inshā', Cairo, 1915.

Sakhāwī, M. Al-Tuḥfa al-lațîfa fì tārīkh al-Madīna al-sharīfa, Beirut, Dār al-kutub al-'ilmiyya, n. d. vol. 1.

Wansharīsī, A. Al-Mi'yār al-Mu'rib wa l-jāmi' al-mughrib 'an fatāwā 'ulamā' Ifrīqiyā waal-Andalus wa-al-Maghrib, Beirut, Dār al-Gharb al-islāmī, 1981.

Zarkashī, M. Tārīkh al-dawlatayn al-muwaḥhidiyya wa-l-ḥafṣiyya, ed. H. Al-Ya'qūbī, Tunis, al-Maktaba al-'atīqa, 1998.

\section{Secondary Literature}

Addas, Cl. La maison muhammadienne. Aperçus de la dévotion au Prophète en mystique musulmane, Paris, Gallimard, 2015.

'Akkām, M. F. "Des fondements de la propriété dans la jurisprudence musulmane. La mainmise sur les biens vacants (al-istīlā' 'alā al-mubāḥ)", in S. Denoix, ed. Biens communs, patrimoines collectifs et gestion communautaire dans les sociétés musulmanes, REMMM, 79-80 (1996), 25-41.

Amri, N. Les saints en islam: Les messagers de l'espérance. Sainteté et eschatologie au Maghreb aux XIV e et XV $V^{e}$ siècles, Paris, Cerf, 2008.

Arié, R. "Les relations diplomatiques et culturelles entre Musulmans d'Espagne et Musulmans d'Orient au temps des Nașrides", in Mélanges de la Casa de Velasquez, 1965/1, 87-107.

Arié, R. "Al-Andalus vu par quelques lettrés orientaux du Moyen Age", in R. Arié, Etudes sur la civilisation de l'Espagne musulmane, Leiden, Brill, 199 o.

Berque J. Le Coran. Essai de traduction, Paris, Albin Michel, 1995.

Bosch-Vilà, J. "Ibn al-Khațîb”, Encyclopédie de l'islam, III, 859-86o.

Chaumont, E. "L'Égo-histoire d'Ibn Khaldūn, historien et soufi", Comptes-rendus des séances de l'Académie des Inscriptions et Belles Lettres, 140-3 (1996), 1041-57.

Dejugnat, Y. "La mer, miroir de la légitimité du califat nașride. A propos du Khațrat al-țayf d'Ibn al-Khatîb (1347)", in C. Picard, ed., La mer et le sacré en Islam médiéval, REMMM, 130 (February 2012), 85-101.

Dhahb̄̄i, N. Abū Muhammad Ṣāliḥ al-Mājirī, al-shaykh wa l-tajriba, Rabat, 2016.

Falāḥ al-Qaysī, F. 'A.-N. Adab al-Rasā’il fì al-Andalus fì al-qarn al-khāmis hijrī, Amman, 1989 . 
Ferhat, H. "Le culte du Prophète au Maroc au XIII ${ }^{\mathrm{e}}$ siècle : organisation du pèlerinage et célébration du Mawlid", in La religion civique à l'époque médiévale et moderne (chrétienté et islam), Actes du colloque de Nanterre, 21-23 juin 1993, Rome, Ecole française de Rome, 1995, 89-97.

Gril, D. "Prophétie et charisme en islam : naissance et renaissance", in G. Filoramo, ed., Carisma profetico. Fattore di innovazione religiosa, Brescia, Morcelliana, 2003, 27-36.

Gril, D. “'Comme s'il y avait des oiseaux sur leur tête'. Entre vénération et amour, l'attitude des Compagnons envers le Prophète", in N. Amri, R. Chih, D. Gril, eds. Le prophète de l'islam : instauration d'un modèle et formes de dévotion, Numéro thématique, Archives de sciences sociales des religions, 178 (July-September 2017), 25-40.

Guichard, P. "La conquête arabe de l'Espagne au miroir des textes", Cahiers d'Etudes Hispaniques Médiévales, 28 (2005), 377-389.

Hamidoune, M. A. "La pratique de la 'prière sur le Prophète' en islam. Analyse philologique et implications doctrinales”, PhD diss., Aix-Marseille Université, 2012.

Ḥaqqī, M. "al-Ḥajj fī al-Maghrib wa al-Andalus fī al-'Așr al-wasìṭ. al-Jidāl ḥawla istimrār farīdat al-hajj [Pilgrimage in the Maghrib and al-Andalus during the medieval period. The debate around the conditions for discharging the legal obligation to perform the Hajj]", in 'Ușūr al-jadìda, VII/26 (winter-spring 2016-2017), 84-101 [consulted online].

Kaptein, N. Muhammad's Birthday Festival. Early history in the Central Muslim Lands and Development in the Muslim West until the 1oth/16th century, Leiden, Brill, 1993.

Lagardère, V. "Terres communes et droits d'usage en al-Andalus ( $\mathrm{X}^{\mathrm{e}}-\mathrm{XV}^{\mathrm{e}}$ siècles)", in S. Denoix, ed. Biens communs, patrimoines collectifs et gestion communautaire dans les sociétés musulmanes, REMMM, 79-80 (1996) 43-54.

Latham, J. D. "Nașrides", in Encyclopédie de l'Islam, 2nd Edition, VII, 1022-30.

Lings, M. Le Prophète Muhammad. Sa vie d'après les sources les plus anciennes, Paris, Seuil, 1986.

Marín, M. "À l'extrémité de l'Islam médiéval : élites urbaines et islamisation en Algarve", Annales. Histoire, Sciences sociales 53/2 (1998), 361-381.

Masson, D. (trans.) Essai d'interprétation du Coran Inimitable, reviewed by S. El-Saleh, Beirut, 198 o.

Nūrīya, A. "Mawlidiyyāt Lisān al-Dīn b. al-Khațīb : mawḍūeātuhā wa simātuhā alfanniyya", Majallat al-Ādāb wa-al-lugha, 21 (2014), 115-136.

Pickthall, M. Roman Transliteration of the Holy Qur'ān with full Arabic text, English translation, Lahore, Qudrat Ullah Co., 2011.

Rubiera Mata, M.-J. "El Califato Nazārī” [The Nasrid Caliphate], Al-Qantara Xxıx/2 (July-December 2008), 293-305.

Torremocha Silva, A. "Les Nașrides de Grenade et les Mérinides du Maghreb", in J. Paez Lopez, ed., Ibn Khaldūn : La Méditerranée au XIVe siècle, Madrid, 2006, 77-85.

Watt, W. M. "al-Anșār", in Encyclopédie de l'Islam, consulted online http://dx.doi .org/10.1163/9789004206106_eifo_SIM_o678. First published online 2010. 